\title{
Elektromagnetiske felt i medisinen - behov for risikovurdering?
}

\author{
Elektromagnetiske felt brukes til stadig flere medisinske utredninger og behandlinger. Grenseverdiene \\ for yrkeseksponering for elektromagnetiske felt er basert på andre eksponeringssituasjoner enn dem \\ som brukes i helsevesenet.
}

Elektromagnetiske felt har ulike frekvenser, og ulik energi. Energien bestemmes også av feltstyrken, som avtar med avstand fra kilden. Innen medisinen brukes elektromagnetiske felt blant annet til diatermi og magnetisk resonanstomografi (MR).

Bruk av elektromagnetiske felt reguleres av lov om strålevern og bruk av stråling for å forebygge skadevirkninger av stråling på mennesker og miljø. Statens strålevern bygger sine anbefalinger på internasjonale retningslinjer. Fra disse er det kjent at kraftige statiske magnetfelt kan gi svimmelhet, kvalme og ulike sanseinntrykk, noe som er dokumentert ved magnetfeltstyrke over $2 \mathrm{~T}$, og der symptomene øker med økende magnetfeltstyrke (1). Grenseverdiene er derfor satt til $2 \mathrm{~T}$ for eksponering av hode/bryst og $8 \mathrm{~T}$ for ekstremiteter.

For tidsvarierende lavfrekvente felt kan høye eksponeringer gi rykninger, lysglimtopplevelser og andre sanseinntrykk fordi det oppstår elektriske spenninger som kan stimulere nerve- og muskelvev. Grenseverdiene for slik eksponering varierer med frekvensen av feltene (2).

Eksponering for sterke radiofrekvente felt kan gi akutt oppvarming av kroppsvev, og vevsskade som følge av dette. Grenseverdiene for tillatt eksponering for radiofrekvente felt er utarbeidet for å forebygge at slik vevsoppvarming skjer. Kroniske effekter av svakere og mer langvarig eksponering er ikke dokumentert i tilstrekkelig grad (3).

Kirurgisk diatermi er en medisinsk metode som benytter radiofrekvente felt til å produsere varme ved den aktive elektroden («kniven») som gir enten en skjærende eller koagulerende effekt i biologisk vev. De ulike elektrodene som benyttes (kirurgens «kniv» og «jordplaten» under pasienten) er koblet med uisolerte ledninger. Studier har dokumentert lokal eksponering på $15 \mathrm{kV} / \mathrm{m}$ for elektriske felt og $16 \mu \mathrm{T}$ for magnetiske felt ved kirurgens hånd (4). Plastsveisere, som vil ha liknende eksponering av hender, er påvist å ha påvirket topunkts diskriminasjon i fingre (5). Eksponeringstid og -varighet vil variere med arbeidsoppgave, og terskelen for påvirkning vites ikke. Det er i helsevesenet manglende fokus på denne eksponeringen i informasjonen om utstyret og hvordan det skal brukes.
$M R$ brukes både i utredning og behandling og gir opphav til statiske magnetfelt samt lavfrekvente og radiofrekvente felt. I Norge benyttes oftest statiske magnetfelt på 1,5 T i MR. Det er i dag en dreining mot å benytte kraftigere feltstyrke for å kunne fremstille bilder med høyere oppløsning.

Økende styrke på statiske magnetfelt i MR gir økende ubehag for pasientene (6). Kraftigere magnetfeltstyrke betyr også at

\section{«Det er også lite kunn- skap om eksponeringen av personalet ved MR»}

det lavfrekvente- og radiofrekvente feltet vil øke i styrke, og nyere forskning har sett reversibelt økt danning av mikrokjerner og andre celleskader hos pasienter ved økende eksponeringer i MR $(7,8)$.

Når det gjelder eksponering for radiofrekvente felt i MR, finnes det lite dokumentasjon. Skannere kan estimere den radiofrekvente eksponeringen gitt til pasientene ved å registrere vekten til pasienten og varsle ved for sterk oppvarming. Å finne eksakte tall på denne eksponeringen er under arbeid, men eksponeringen er svært spesiell og vanskelig å forutsi, bestående av svært kortvarige og sterke pulser, og det er lite kunnskap om hva slags virkning slike pulser har.

Det er også lite kunnskap om eksponeringen av personalet ved MR. Dette varierer ut fra arbeidsoppgaver og bruken av MR (9). I EUs nye direktiv 2013/35/EU, som for tiden er på høring i Norge, har EU valgt å definere MR og ansatte rundt som unntatt fra direktivet, da eksponeringsgrensene ikke kan overholdes ved MR (10). Dette nødvendiggjør oppfølging av MR-personell med tanke på eventuelle uheldige virkninger av arbeid ved MR-skannere.

Jeg takker Bente E. Moen, Gunnhild Oftedal, Valborg Baste og Kjell Hansson Mild for gode innspill til artikkelen.
Ole Jacob Møllerløkken

ole.mollerlokken@igs.uib.no

Ole Jacob Møllerløkken (f. 1980) er cand.med. med forskerlinje, har doktorgrad i arbeidsmedisin og arbeider ved Arbeids-og miljømedisin, Universitetet i Bergen.

Forfatter har fylt ut ICMJE-skjemaet og oppgir ingen interessekonflikter.

\section{Litteratur}

1. International Commission on Non-lonizing Radiation Protection. Guidelines on limits of exposure to static magnetic fields. Health Phys 2009; 96 : 504-14.

2. International Commission on Non-lonizing Radiation Protection. Guidelines for limiting exposure to time-varying electric and magnetic fields (1 Hz to $100 \mathrm{kHz}$ ). Health Phys 2010; 99: 818-36.

3. International Commission on Non-lonizing Radiation Protection. Guidelines for limiting exposure to time-varying electric, magnetic, and electromagnetic fields (up to $300 \mathrm{GHz}$ ). Health Phys 1998; 74: 494-522.

4. Liljestrand B, Sandström M, Hansson Mild K. RF Exposure During Use of Electrosurgical Units. Electromagn Biol Med 2003; 22: 5.

5. Kolmodin-Hedman B, Hansson Mild K, Hagberg M et al. Health problems among operators of plastic welding machines and exposure to radiofrequency electromagnetic fields. Int Arch Occup Environ Health 1988; 60: 243-7.

6. Heilmaier C, Theysohn JM, Maderwald S et al. A large-scale study on subjective perception of discomfort during 7 and 1.5T MRI examinations. Bioelectromagnetics 2011; 32: 610-9.

7. Fiechter M, Stehli J, Fuchs TA et al. Impact of cardiac magnetic resonance imaging on human lymphocyte DNA integrity. Eur Heart J 2013; 34: 2340-5.

8. Knuuti J, Saraste A, Kallio M et al. Is cardiac magnetic resonance imaging causing DNA damage? Eur Heart J 2013; 34: 2337-9.

9. Hansson Mild K, Hand J, Hietanen M et al. Exposure classification of MRI workers in epidemiological studies. Bioelectromagnetics 2013; 34: $81-4$

10. Keevil SF, Lomas DJ. The European Union physical agents (electromagnetic fields) directive: an update for the MRI community. Br J Radiol 2013; 86: 20130492.

Mottatt 10.12. 2013 og godkjent 21.1. 2014. Redaktør: Matilde Risopatron Berg.

Publisert først på nett. 